\title{
Research on Specialized Construction of College Counselors
}

\author{
Junzheng Wang ${ }^{1, a}$ and Guixue $\mathrm{Hu}^{2,} \mathrm{~b}^{*}$ \\ ${ }^{1,2}$ College of Engineering and Technology, Jilin Agricultural University, Xincheng Street 2888, \\ Changchun, Jilin Province 130118, PR China \\ a595845966 @ qq.com; guixue1964@126.com \\ ${ }^{*}$ The corresponding author
}

Keywords: College counselors; Team specialization; Construction

\begin{abstract}
College counselors are the most important educators in college. They are the core teachers who manage students and are the soul tutors of students' growth. At present, the social environment change rapidly and the diversification of the development of science and technology continue to affect the lives of students, therefore, the construction of University Instructors' specialization is particularly important. This article from the college counselor specialization construction connotation, the construction process the existence question and the three aspects to elaborate, hoping to the university counselor specialized construction to provide the beneficial enlightenment.
\end{abstract}

\section{Introduction}

The professionalization of the college counselor ranks, in which "specialization" refers to "a professional after a certain period of time after the maturing, and gradually get a clear professional standards, and access to the corresponding professional status of the process." As a part of the faculty of the university teachers, the counselors are not only concerned with the academic achievement of the college students, but also pay attention to the life and mentality of the college students, and guide the students to the correct way of life. Plays an important role in national development and ideological and political education of college students. In the diversified global environment, the ideological and political education of college students is facing severe challenges, how to improve the professionalism of counselors is an effective measure to solve this problem.

\section{The Connotation of Specialized Construction of College Counselors}

The professionalization process of college counselors is to rely on specialized institutions and lifelong professional training system, the scientific management and training of counselors, so that counselors master the moral education work and student management knowledge and skills, the implementation of professional autonomy, professional performance Morality, improve academic status and social status, and fully and effectively perform the duties of counselors. The professionalization should include two aspects of content, on the one hand is the college counselors learned the professionalism, including management, psychology, education and other disciplines, on the other hand refers to the professional ability of college counselors, that is, In the specific application management methods, learn to sum up innovation, can not improve their own teaching ability. College counselors specialized elements are the following:

Have a high professional ethics and specialized knowledge and skills, patient and helpful, do their best for students to solve learning and life difficulties, there is a pair of insight into all the eyes, the timely detection of students' ideological changes.

A professional team, which members have received vocational training, with good professionalism.

To continue to learn and sum up, learn from previous experience to learn, and constantly improve their ability. 
Can combine theory with practice, rather than the theory from reality, just on paper, which can continue from the practice of innovation.

Have a greater authority and autonomy to your profession.

Their social status and academic status can continue to improve.

The college counselor is the mentor and implementer of the ideological and political education of college students. It is the guide of the road of life of college students. Therefore, it is of great significance to strengthen the specialization of college counselors.

\section{The Problems in the Process of Specialized Construction of College Counselors}

Missing Counselors Professional Assessment System. Although the counselor of this career already has more than sixty years of history, and now almost all of the different colleges and universities, different grades are equipped with counselors, but counselors professional assessment system has not been clear, in the country, The counselor's selection did not have a uniform measure. At present, the majority of college counselors from the outstanding undergraduate graduates or graduate students, there is no professional requirements, so they need to spend more energy to understand the work of counselors, and students get along Need to spend more time to run, greatly reducing the efficiency of ideological and political education of college students. Therefore, the establishment of college counselors or related professional is very necessary.

Counselors Team Instability. Counselor specialization requires a stable counselor team, but the current situation of various colleges and universities is the mobility of counselors, mainly due to the work of counselors complex, low economic income, the lack of a certain space for development, so most of the counseling The job is only the "springboard" of the job, not as a lifelong career to pursue, when they find a better career, they will naturally quit, but at this time they have accumulated some experience no Wasted. Counselor of this career is the need to continue to accumulate experience, and constantly explore, in order to assume the responsibility of college students tutor.

Counselor Role Dislocation, the Responsibility Is Not Clear. Counselor's primary task is to conduct ideological and political education of students, of course, also need to involve the relevant student affairs. However, because the counselor is the closest to a college student's position, so the school's security office, the Office of Academic Affairs, Finance and other departments have a job will be arranged to the counselor, resulting in a variety of work will fall on the shoulders of the counselor, So that counselors busy in these complicated affairs, and not enough time on the ideological and political education of college students, the ideological problems of college students can not find effective measures to solve and reduce the ideological and political education of college students effectiveness. At present, business managers can be used to describe the identity of counselors, students from the growth path on the road of life tutor there are a lot of distance. University counselors if the work of the carrier and the work of the contents of the cart before the horse, it is an unwise choice.

Less Than Training Time, Low Degree of Specialization. As a result of recruiting counselors rarely require professional, usually excellent undergraduate graduates or graduate students, as long as the study of excellence, comprehensive quality can be high, so the latter part of the professional training of counselors is very necessary. There are a lot of drawbacks in the training model of counselors used in colleges and universities in our country: the number of participants is limited and the period is long. The time of the counselor's training is very short. Most of the training content is to impart knowledge, communicate and exchange experiences. Stay away from practical work. The contents of ideological and political education for college students include: political, ideological and mental health education and many other aspects of the content, which requires college counselors not only to have a high overall quality, but also a variety of subject background, so improve the professionalism of college counselors long way to go. 


\section{The College Counselors Professional Construction of the Countermeasures}

Improve the Counselor Professional Assessment System and Appointment System. It is recommended that colleges and universities in the selection of counselors to form a unified rule, the professional, academic qualifications, ability to set the same standards, such as undergraduate or graduate, member of the Communist Party of China, during the student cadre experience, a strong responsibility center, The corresponding subject background, etc., it is best like the state or the provinces choose civil servants, held a unified "entry" examination, if the examination is qualified, issued by the corresponding counselor career qualification certificate. In the selection, to adhere to the "fair and just, equal competition," the principle, so relatively more fair for everyone, but also from the source to regulate the counselors. Some colleges and universities can also be based on the school's own conditions, the establishment of "counselor" this professional, so that the future of counselors in this career before the students in the professional training before, so, after taking office can be handy. To strictly implement the counselor professional assessment system and the appointment system, choose a real fit for the career of the mentor, so that the professional development of counselors more stable.

Build Specialized Training Mechanisms to Improve the Professional Skills of Counselors. As a college counselor, it is necessary to manage the basic theory of Marxism, psychology, situation and policy, education and other related disciplines background, so colleges and universities should often organize some relevant knowledge of lectures, training, academic salons and other activities. For the training of college counselors can not be generalized, should be based on the counselor's duties, age, specific positions for targeted training, training content and work content should be consistent, improve the efficiency of training. Colleges and universities can also hold some campus exchanges, the theme of the report will promote the exchange of counselors between schools, learn from each other experience. You can also regularly invite some teachers to conduct academic lectures, broaden our horizons. Counselors not only to improve their level of professional knowledge, but also more analysis of the real case, learn to analyze the psychology of college students, for some of the new things may bring the impact of prevention in the event of a variety of unexpected conditions to calm and fast Find an effective solution. It is an important condition to promote the professional construction of counselors and improve the professional skills and quality of counselors.

Clear Counselor Responsibilities, Effectively Improve Management Efficiency. Counselors professional construction of the premise and basis is to clarify the duties of counselors in order to avoid blindly into the work, and effectively assume their own responsibility. Counselors in the growth of college students play mainly managers, educators and service these three roles, in short, its job responsibilities include the following three aspects: First, the ideological and political education of college students, counselors based on Their own theoretical knowledge, the values of students, outlook on life, world view of education, mental health education, legal education, personal safety education, so as to improve the ideological awareness of college students and political theory. The second is to manage the daily affairs of college students, according to the management of college students in the rules and regulations, do a good job of college students learning style, bedroom housekeeping, community management, poverty subsidies, scholarship selection, employment services and other work. Third, to create a good campus environment, regularly carry out various academic activities, to stimulate students' interest in learning, improve the ability to innovate, you can also carry out some extracurricular activities, such as calligraphy exhibition, exhibition, singing competition, speech contest, dance contest and other activities, So that college students out of the bedroom, give them a variety of talents to provide opportunities to achieve "moral, intellectual, physical, beauty, labor" all-round development. As a counselor with the students contact most occupation, we should always pay attention to the ideological change, find the topic and students together, to mingle with the students, college students spiritual friend, to perform any work which can be effective.

To Establish a Scientific Incentive Mechanism, Improve the Promotion Mechanism of College Counselors. The establishment of a promotion mechanism allows college counselors to see 
their career in the future, to stimulate their enthusiasm has been to dry down to reduce the counselor "quit" phenomenon, improve the relative stability of the counselor team. So the various colleges and universities can be based on their own laws and regulations, the characteristics of counselors to develop assessment system to review the counselors for college students daily affairs and ideological and political education of college students to deal with the situation, the details of the assessment criteria to be specific, Job-related, reward and punishment clearly, fair treatment of each counselor. For long-term assessment of excellent counselors, you can improve the treatment, promotion work or enhance the title. The establishment of scientific incentive mechanism and improve the promotion mechanism of college counselors, teachers can fully mobilize the enthusiasm of the work is to promote the professional development of counselors team of favorable protection.

\section{Conclusion}

The specialization of college counselors is the necessary means to improve the level of higher education in our country. It is an inevitable requirement to guide the healthy growth and happiness of college students. It is also the inevitable trend of the professionalization of college counselors. From the current point of view, the professionalism of the counselor team is a long and arduous process that requires counselors to study, practice and accumulate experience. Therefore, the college counselors must first establish a firm professional beliefs and lofty professional ideals, the counselors as their own career to pursue their own, clear their duties, take the initiative to learn, constantly enrich themselves, enhance themselves and actively participate in various counseling Training, to learn from others, face new problems, new challenges, or fear, do not back down, dare to accept the challenge, to be diligent in thinking, to find a viable solution, and constantly create new work performance. College counselors can communicate with college students, care about their study and life, do their best to help them encounter problems, with their own charisma to infect them, to enhance their relationship with the students, and strive to become college students life instructor Mentor. Through the above methods, efforts to make the college counselors team onto the professional development of the track, so that colleges and universities can form a good teaching style, style of study and school spirit, so that school accidents to a minimum, students can concentrate on learning, Healthy growth, in order to take the motherland in the future needs of the post, for the development of the motherland to make their own contribution, so that the education of colleges and universities can be accepted by the broad masses of the people, which can get a good reputation. Therefore, the college counselors team of professional construction is imminent, the need for the community to make efforts, I believe in the near future, counselors professional, professional will be able to achieve.

\section{Acknowledgements}

This article is the research work of the Chinese Society of Higher Education Student Work Research Branch 2016 years of college students work research topic "college counselor specialization construction research" (subject approval number: LX2016Y013) research results.

\section{References}

[1] The Ministry of Education teacher division teacher professional theory and practice [M]. Beijing: People's Education Press, 2001.

[2] G Feng, Ideological and political education innovation and development research [M]. Beijing: Renmin University of China press, 2009.

[3] Y.B Jin., Instructor team specialization connotation and way [J]. Ideological Education Research, 2007 (9). 
[4] X.C Li, Counselors professionalization of professional construction countermeasures [J]. Ideological Education Research, 2007 (12).

[5] Y.T Chen, Counselors specialization and professional construction of a number of thinking [J]. Journal of Ideological and Political Education, 2007 (6).

[6] Q.H Peng, On the specialization of college counselors [J]. Journal of University of Science and Technology Beijing: Social Science Edition, 2007 (4).

[7] the Ministry of Education. teacher division teacher professional theory and practice [M]. Beijing: People's Education Press, 2001.

[8] B.W Zhang, N Lin, College counselors professional development dilemma [J]. China Higher

[9] C.R Shi, Journal of college counselors professional construction of J]. Liaoning Administration Institute, 2008, (1): 195

[10]C.X Liang, College political counselors specialization, professionalization of the higher education research, 2006, (11): 35-47.

[11] Q.H Peng, On the specialization of college counselors [J]. Journal of University of Science and Technology Beijing, 2007 (4).

[12] S.Y Liu, Reflections on College Counselors' professional [J]. ideological education Herald, 2007 (7): 63. 